\title{
On The Antiquities Of Algeria
}

\author{
the Lord Talbot De Malahide P.R.I.A., F.R.S., F.S.A.
}

To cite this article: the Lord Talbot De Malahide P.R.I.A., F.R.S., F.S.A. (1882) On The Antiquities Of Algeria, Archaeological Journal, 39:1, 227-238, DOI: 10.1080/00665983.1882.10852035

To link to this article: http://dx.doi.org/10.1080/00665983.1882.10852035

$$
\text { 曲 Published online: 14 Jul } 2014 .
$$

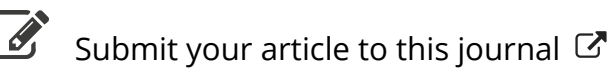

Q View related articles $₫$ 


\section{ON THE ANTIQUITIES OF ALGERIA.1}

By the Lord TALBOT DE MALAHIDE, P.R.I.A., F.R.S., F.S.A.

I do not presume to describe in detail the antiquities of North Africa. They are too numerous and multifarious. I shall confine myself to a selection of some of the most interesting monuments, and point out how the inscriptions illustrate the history and administration of this important province.

Two countrymen of our own have led the way, and in spite of natural prejudices and antipathies the French antiquaries do full justice to the discoveries of Shaw and Bruce.

Since the conquest of Algiers, the French, although they have in many instances rivalled their predecessors the Vandals, in the destruction of ancient monuments, have produced some very learned and zealous inquirers. They have formed several provincial Antiquarian Societies who have done good work in preserving many ancient relics, and have published valuable journals. The Society of Algiers has published the Revue Africaine, which contains an immense mass of information, and the Society of Constantine publish a still more interesting recueil.

Among the many contributors to these journals, Messrs. Berbrugger, Cherbonneau, Dr. Leclerc, Dr. Reboud, the late Baron Aucapitaine have been the most remarkable; and for Arabian history and antiquities the late Baron de Slane, M. Brosselard, and M. Feraud the present Consul at Tripoli, with many others, have contributed greatly to our knowledge of the troublous times which succeeded the Moslem conquest. I should be unjust if I omitted to mention the name of our learned and zealous Consul General, Colonel Playfair, to whose excellent

${ }^{1}$ Read in the Section of Antiquities at the Carlisle Meeting 'August'1st, 1882. 
hand-book of Algeria I am much indebted for some of the details in the present address.

I presume that all my auditors are well acquainted with the geography of North Africa. I shall merely remind them that, previous to the Roman conquest, the sea board from Cyrene to the Straits of Gibraltar, was occupied by the Carthaginians and their colonies. They never seem to have conquered Cyrene, which always remained Greek, and the inhabitants of the interior of the country enjoyed a kind of semi-independence, under the name of Massyli Massosyli, Gatula, and generally the name of Mauri.

After the destruction of Carthage, the district comprised in the kingdom of Morocco and Algeria was divided between the descendants of Masinissa and Bocchus, but ultimately was reduced to the state of two Roman provinces, under the name of Mauritania Tingitana and Cæsareansis. There were subsequent sub-divisions which it is needless to advert to.

The Romans, however, never gave up the province of Carthage, now the Regency of Tunis, but it became a proconsular province and was generally styled Africa.

Many stirring events occurred during the Roman dominion, until the invasion of the Vandals, and the ultimate conquest by the Arabs utterly subverted the government of this dependency, and in great part destroyed the advanced civilisation of one of the richest and most prosperous provinces of the Roman Empire.

I shall not enter into the history of Arab times or the civil wars between the different Berber Emperors; ultimately Barbarossa extinguished them, and subjected Algiers, Bougie, Constantine, and Oran to the rule of a horde of Turkish mercenaries, who, like Arabi Bey, plunged the country into anarchy and oppressed with a cruel yoke all classes of its inhabitants.

In considering the antiquities more in detail, I shall first mention what traces we find of the different occupiers of this country.

1. The Libyans were the aborigines, according to the most trustworthy accounts of themselves. The present Kabyles and Berbers are with great probability supposed to represent this race. Although many tribes may be 
mixed with Roman, Vandal, and Jewish blood, they have many traditions which confirm this supposition. They speak also a Berber language, perfectly distinct from the Punic and Arabic, and many Berber inscriptions are found in a peculiar character which Messrs. Faidherbe and Hanoteau have proved to be closely allied with one still existing in one of the most numerous African races, the Touareks. I shall not attempt to treat the physiological branch of the subject. When I come to treat of the Dolmens, I shall consider their relation to them.

2. The Carthaginians have left considerable memorials of themselves. I am not aware of any building in Algeria that can be said to belong to them, but numerous inscriptions in Punic and Neo-Punic have been found at VielArzeu, Jol Crsarea (now Cherchell), but the greatest number at Guelma (the ancient Calama), and Constantine ; El Hofra, near Constantine, contained 130.

3. The Romans. I shall speak at greater length of their remains in a subsequent part of this address.

4. The Vandals. I am not aware of any remains which can with any certainty be ascribed to them, unless some of the Christian inscriptions belong to this period.

5. The Saracens. Most interesting remains of them still exist, principally at Tlemecen, but I shall not treat of them on the present occasion.

In describing the pre-Roman tombs, the Royal tombs claim the precedence, and I shall therefore give you a short account of the remarkable monuments called the Tombeau de la Chretienne and the Medrasen.

The Tombeau de la Chretienne is a circular building of stone, about 131 feet in height originally, now about 100 feet 8 inches. The base is 198 in diameter and forms an encircling podium of a decorative character, presenting a vertical wall with 60 engaged Ionic columns; surmounted by a frieze and cornice of a simple form. The colonnade has at the cardinal points 4 false doors, the four panels of which producing what may have been taken for a cross, probably contributed to fix the appellation of Christian to it. Above the cornice rose a series of 33 steps which gradually decrease in circular area, giving the building the appearance of a truncated cone. The whole monument is placed on a low platform. 
There have been various attempts to penetrate into the interior. The tombs have been rifled, but were never thoroughly explored till Messrs. Berbrugger and Macarthy were charged by the late Emperor Napoleon to give it a thorough investigation, and they have published an interesting report.

In the interior a large gallery was discovered, which wound round in a spiral direction, gradually approaching the centre, where are two sepulchral vaulted chambers separated by a short passage, and shut off from the winding passage by stone doors, consisting of a single slab capable of being moved up and down by levers like a portcullis.

Pomponius Mela mentions it as monumentun commune Regice gentis, and it is supposed to have contained the remains of Juba II and Cleopatra Selene his wife. $\mathrm{He}$ obtained from Augustus the half of his father's kingdom, and his capital, instead of Cirta, became JolCæsarea (the modern Cherchell.) The tomb is very near that city.

In one of the small chambers, there were found some Egyptian beads and the fragments of an Egyptian necklace, which confirmas the idea of Cleopatra having been buried there. She evidently kept up her Egyptian traditions as an Egyptian statue of Isis has been found at Chirchell.

The Medrasen or Madrasen near Batna is perhaps still more interesting. It is certainly more ancient than the Tombeau de la Chrétienne, and the latter was evidently an imitation of it.

Like the tombeau, its form is that of a truncated cone placed on a cylindrical base 19:3 feet in diameter, the total height is 60 feet. The lower portion, which forms a vertical encircling zone or ring, is ornamented by 60 engaged columns, of which one half are now perfect. The upper part gradually diminishes by a series of steps. The columns are stunted; they rest on three steps which serve as base both to the monument and the columns.

The capitals are Doric, and above them is an entablature, with a large bold cavetto, as if of Egyptian origin.

At the east end also, a rectangular enclosure has been discovered, similar to the one attached to the Tombeau de la 
Chretienne. It probably served for depositing the corpse before burial or for burning it.

The exterior masonry is very fine, the stones of great size, well cut, and close fitted, and each stone joined to its neighbour by a massive clamp probably of lead, the search for which has greatly contributed to the destruction of the building. A central chamber has been discovered, but nothing of interest was found in it, as it had been previously rifled.

It has been popularly called, and is so still by the natives, the tomb of Syphax, and it figured at the great Paris Exhibition of 1861, where there was a large model of it, under his name. But in all probability it was a tomb of the Numidian kings, probably of Masinissa. The date B.c. 150 has been assigned to it. Some believe it to have been erected by Masinissa himself, others by Micipsa.

This tomb has been compared to the mausoleum of Augustus and also to that of Hadrian to which it bears some resemblance, but it resembles more the tomb of Alyattes near Sardes and some of the Etruscan tombs.

I shall not dwell much on the Libyan inscriptions, but merely state that they are found in very many localities. At the cemetery of Chorfa between Constantine and Guelma 18 have been found, and near Souk-Arras (ancient Tagaste) 49. Drs. Judas and Reboud have been very active in collecting them, but I hardly believe that they have made much progress in decyphering them.

The Dolmens, certainly in great part, belong to a very early period. They are very numerous at Roknia (near Hamman-Meskitin). There are said to be as many as 1200 , but they are mostly small, and none of them have inscriptions. They have also been found at Sigus, BenMerzoug, Nemencha, Omm-el-Ashara, Djelfa, Ras-el-Akba, Oued-Berbes, Formel Mabuk, and Mc Guib near Bona and other places.

M. Masqueray, in his report to the Exposition Universelle de Paris, 1878 , speaking of the ruins of Ain-Ghnab in the Sahara, says that there are found megalithic monuments with a cover, and supporting stones worked and apparently derived from Roman ruins.

In one place there is found a kind of sarcophagus and surrounded by a circle of stones which show that it is 
Berber and megalithic. The megalithic monuments found in the neighbourhood of Madid, Guelma, \&c., are very numerous, and it would seem that they have been built at different periods down to the introduction of Islamism. Articles of bronze and even iron are said to have been found in them, and in one instance a medal of the Empress Faustina.

Near Negrim, at the ruins of the ancient Besseriani, a manufactory of flint instruments or weapons has been discovered.

I should not do justice to this part of the subject if before concluding I did not give some account of Dr. Reboud's ingenious theory for determining the age of the Dolmens of Rocknia.

He excavated 28 of these, and found in them bones, and mixed with these thousands of dead snails, those contained in the humus which lined the bottom of the tombs were of extinct forms. But he found of the Helix aspusa 7 species extinct and 20 very rare. Their form strongly resembles those common in the north of France. The conclusions he draws are as follows:- "Ces especes n'indiquent, que peu à peu, le climat de Rocknia est devenu plus sec et plus brulant, que petit a petit, les forets, ne reçevant assez d'humidite, ont disparu, enfin que ce pays a fini par devenir, ce qu'il est aujourd'hui, sec et chaud."

The average height of the thermometer at Rocknia is, according to him, $17^{\circ} 50^{\prime}$, and comparing it with that of Paris, $10^{\circ} 1$ ', he says :- "Il y a donc entre le climat des regions Algeriennes ou s'elevent les monuments dolménigues et celui du nord de la France une difference de $7^{\circ} 50^{\prime}$ et 95 jours de pluie, ce qui implique pour l'Epoque du deblayement des tumulus au pays de Rocknia, une temperature pres de deux fois plus froide et deux fois plus humide."

I cannot go into all his curious calculations, but the upshot is that in order to create the difference of climate which is proved by the snails, it is necessary to allow a period to have elapsed which would carry the date of these Dolmens to B.c. 2200.

He accounts for these climatic changes, by-

1. The variation of the eccentricity of the earth's orbit. 
2. The variation of the obliquity of the ecliptic.

3. The precession of the equinoxes, combined with the movement of the apsidal line.

The antiquities of the Roman period are much the most numerous and important. The whole soil "of Algeria and Tunis is thickly studded with the remains of Roman cities, municipia and villages, even in the Sahara. They mostly belong to a late period of Roman domination. But a considerable number of inscriptions appertain to the era of the Flavian family and the Antonines. They became almost innumerable at the period of Septimius Severus and Caracalla, and are very frequent during the succeeding emperors and the Byzantine period. The remains consist of-

1. Amphitheatres; almost every town appears to have had one. There is still in tolerable preservation one at Cherchell, the ancient Jol-Cæsarea, and I have counted as many as twelve in the Province of Tunis.

2. Temples. But few of these have been preserved in Algeria, until the French occupation there was a considerable one at Cherchell. And there are still remains of temples at Lambessa and Tebessa.

3. Triumphal arches. It appears to have been the fashion for decuriones and other municipal officers to erect them in honour of the reigning monarch. There are several remaining at Lambessa and Tebessa.

4. Waterworks. The Romans did not neglect this important matter, one of life and death to the agriculturists of Africa. There are considerable remains of an aqueduct at Cherchell, and also at Constantine. There are also some remains at Lambessa and Tebessa. Besides the aqueducts, there are numerous wells, and canals for irsigation which owe their existence to this intelligent people.

4. There are numerous remains of fortifications of this period; all the principal towns were fortified. At the present time there are some traces of them on the walls of Constantine, and there are numerous forts which have been restored during the reign of the Byzantine Emperors.

But few of the Roman colonies or municipia appear to have struck coins, and those who did so were purtially Car- 
thaginian, as appears by their Punic inscriptions. However there are a few with Latin inscriptions such as Cæsarea, Cirta, Hoppo-Diarrhytus and Utica. Carthage, I need hardly mention, struck a great many, and some are of great beauty, evidently copied from the medals of Panormus, Agrigentum and Syracuse.

Many statues have been discovered, particularly at Cæsarea, Rusicada and Lambessa, but they seldom are of much artistic value, and the best have found their way to the gallery of the Louvre.

Numerous mosaics have been found and many of them both curious and effective. Those found in the tomb of Præcilius, which I believe do no longer exist, were among the most remarkable.

There are not as many remains of Christianity as might be expected, but the remains of several basilicæ, one, a very remarkable one, at Tebessa, and also one at Orleansville, bear witness to the conversion of Africa. In the cemeteries also Christian inscriptions are not rare.

I have not yet mentioned the cemeteries which are most important and have produced an immense number of inscriptions. Messrs. Reiner and Willman have formed large collections. The latter, under the auspices of the Academy of Berlin, has printed as many as 10,098, and every day fresh ones come to light. I may however observe that they are not confined to Algeria, a great many belong to Tunisia, and there are numerous milliary and votive inscriptions.

I shall now consider the inscriptions, which form the most instructive portion of Roman remains, and I shall endeavour to glance at the many subjects connected with Roman dominion and administration, and also the manners of the people on which they throw light.

First, the public inscriptions.

The Duumviri or decuriones of the African colonies, particularly during the reigns of Septimius Severus, Caracalla, and also the later ones, Constantine, Constantius, Valentinian, and even Honorius were in the habit of erecting triumphal arches with honorary inscriptions to these emperors.

The adulation and falsity of some of these is inconceivable. One would pardon them for speaking of the 
reign of Constantine as beatissimo sceculo. But it is incredible that men could have the impudence in the time of Valentinian and Valerius to speak of their beatissimis temporibus. Evidently Valerius had not then been defeated and burnt alive. They speak of Honorius and Theodosius II in the following terms-beatissimis temporibus dominorum nostorum Honorii et Theodosii semper et ubique vincentium. I suppose that Rome had not then been sacked. Perhaps it had.

But few Greek inscriptions have been found in Algeria. However, there were two very curious ones at Constantine. They are honorary and are dedicated to P. Julius Geminius Marcianus, legatus Augustorum, by the Bou $\eta$ кa

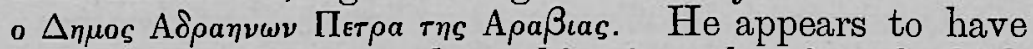
been prætor or proconsul at this city, the site of which does not seem to be very certain.

From these inscriptions a long list of local African deities can be compiled. The principal ones are-

1. Aulisva at Tlemeæn (Pomaria).

2. Aulius at Aumale (Auzia).

3. Molmanius at Lambessa.

4. Bacac at Djebel-Taia.

5. Baldir at Guelat-bon-seba near Guelma.

6. Malagbel at El-Kantara near Biscara.

7. Goddess Gelva at Guelma.

8. Eruc at Khubet-Guidra near Sesteia.

Besides very numerous protecting genii of different colonies.

A considerable portion of these inscriptions refer to soldiers, particularly those in the neighbourhood of Lambessa, which for some centuries was the head-quarters of the 3rd Legion Augusta. They illustrate in a remarkable manner the works of Vegetius, and mention the names of officers whose existence was hardly known.

Besides the Roman legion, there was a large force of provincial levies or auxiliaries, who appear to have been collected from all parts of the empire, and even beyond it.

I have found the names of the-

Breuci, Sicambri, Cimbriani and Marcomanni (evidently Teutonic).

The Celtæ and Britanni.

Astures and Hispani. 
Brace (Portuguese).

Sardi.

Delmattæ.

Pannonii.

Commageni.

Thraces, and

Parthians who were Equites sagittarii, and who formed two bodies, seniores and juniores.

Two Palmyrene bilingual inscriptions have been found which probably belonged either to the Parthians or the Commageni.

Municipal inscriptions. Many of these refer to their officers.

Q. Quadratus held offices in the Cirtean Confederation (Cirta, Rusicada, Chullu and Melev.) A votive offering on his part to Bacchus informs us that he presented a statue with a chapel to his God, and also the sum of $20,000 \mathrm{hs}$ when he was decurio.

Another gentleman of Cirta who had obtained the honour of edilis, triumvir, quinquennalis, besides paying the regulation sum of $20,000 \mathrm{hs}$. for each office, presented to the town the statue of the goddess Securitas with its tetrastyle chapel, a statue of Indulgentia Imperatoris, and another of Virtus principis. He also erected a triumphal arch and gave seven days of theatrical representations and missitia to the four colonies.

He must have been enormously rich and his example is an instructive one for our immaculate boroughs. In such cases, it was usual for the cities in return to present their benefactor with a public horse and a statue with a complimentary inscription.

These inscriptions have shown a very curious statistical fact-the great longevity of the Romans in Africa. Dr. Leclerc has made a curious summary of his examination of these funeral records.

He reckons 90 deaths between the ages of 90 to 100 , and 230 between 80 and 90 . Confining himself to the Province of Constantine, he reckons 37 between 100 and 107 ; between 108 and 125, thirteen; and one of 126 , one of 127 , one of 131 , and one of 132

I will now give a selection of some of the most curious funeral inscriptions. 
The most remarkable one that has been lately discovered is that of Præcilius, a centenarian, and a goldsmith of Cirta or Constantine. His tomb was a most interesting one, of considerable size and adorned with mosaics and statues. However, the French have allowed it to be gutted and destroyed. He was not a modest man, although supposed to be a Christian. He left a long epitaph in verse, not the most classical, in praise of himself. I shall not quote it at length but only a few lines-

Hic ego qui taceo versibus meam vitam demonstro.

Lucem claram fruitus et tempora summa

Præcilius, Cirtensi lare, argentariam exibui artem,

Fydes in me mira fuit, et veritas omnis

Omnibus communis ego. Cui non misertus ubique?

Risus, luxuriam semper fruitus cum cari amicis

Talem post obitum dominæ Valeriæ non inveni pudicæ

Vitam ; cum potui gratam, habui cum conjuge sanctam,

Natalis honeste meos centum celebravi felices.

Here I am, silent, describing my life in verse.

I enjoyed a bright reputation, and the height of prosperity.

Præcilius by name, a native of Cirta, I exercised the art of a goldsmith. My honesty was proverbial, and I always adhered to truth.

I was civil to all men, and what distressed man did I ever refuse to succour? I was always gay and hospitable to my dear friends.

But a great change came over me by the death of the virtuous

Lady Valeria. As long as I could, I enjoyed the sweets of holy matrimony. I have celebrated my hundredth happy birthday.

The domestic funerary inscriptions form the most numerous portion, and certainly appear to prove that the Romans were a domestic nation.

I will begin with one which appears to have been erected to an Irish woman and her husband who was probably a Briton--

\author{
D. M. S. \\ CANTONI \\ VS FELIX VE \\ VIX ANN LXII \\ MVI Et AuRE \\ LAE IBERNNE \\ VIX ANN LVII \\ BALLANTVS \\ FLVS EORA \\ H. S. E.
}

Sacred to the gods manes. Caius Antonius Felix a veteran, he lived 62 years six months, and Aurelia, native of Ireland, who lived 67 years. Erected by their son Ballantus.

Ballantus resembles an Irish name.

This was found at Ain-Csar near Lambessa, 
Maria seems to be a name used by heathens as well as Christians.

Here is another-

D. $\mathrm{M}$.

MARIA Q

VNTILLA

VIXIT ANN

OS LXXXV

\section{HIC SITA EST AMYMONE \\ MARCI OPTIMA ET PVLCHERRI \\ MA LANIFICA PIA PVDICA \\ FRVGI CASTA DOMISEDA}

I think it hardly possible to exceed that.

Here is one which shows that ladies were not cyphers in their households-

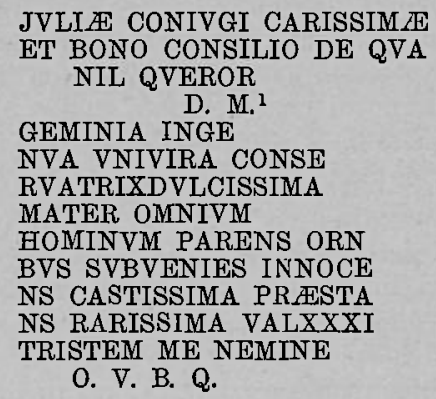

I could quote these affectionate inscriptions by hundreds. I will, however, give you those epithets which I generally found applied to wives-
Rarissima,
Obsequentissima,
Benegnissima,
Carissima,
Sanctissima,
Dilectissima.

Wives seem to have been equally flattering to their husbands, and styled them-

\section{Rarissimo, \\ Carissimo. \\ Incomparabili,}

and in one instance

\section{Obsequentissimo.}

Here is an example for the present generation.

1 This lady's merit was having had one husband, 